J. Clin. Chem. Clin. Biochem.

Vol. 27, 1989, pp. $851-856$

(C) 1989 Walter de Gruyter \& Co.

Berlin - New York

\title{
Changes in the Concentrations of Hydroxyproline, Glycine and Serine in the Plasma of Haemodialysis Patients Undergoing Erythropoietin Therapy
}

\author{
By E. Riedel, M. Nündel, B. Algermissen
}

Freie Universität Berlin, Institut für Biochemie

\section{Hannelore Hampl}

Freie Universität Berlin, Klinikum Rudolf Virchow, Abteilung für Innere Medizin mit Schwerpunkt Nephrologie

\section{P. Scigalla}

Fa. Boehringer Mannheim GmbH, Abteilung Klinische Entwicklung Salvia and

\section{U. Stabell}

Institut für Nuclearmedizin, Dillenburgerstraße, Berlin 33

(Received August 25, 1988//May 9/August 10, 1989)

\begin{abstract}
Summary: The concentrations of proline, hydroxyproline, glycine and serine were determined in the plasma of 39 haemodialysis patients and 18 healthy subjects, using liquid chromatography with fluorescence detection. Plasma concentrations of the N-terminal immunoreactive parathyrin were also measured. In haemodialysis patients, the plasma concentrations of glycine $(p<0.01)$, hydroxyproline $(p<0.05)$ and proline $(p<0.10)$ were significantly increased, whereas the serine concentrations $(p<0.01)$ were decreased, compared with those of the healthy controls. Haemodialysis patients showed greatly elevated plasma $\mathrm{N}$-terminal immunoreactive parathyrin values $(>30 \mathrm{pmol} / \mathrm{l})$, which showed a significant correlation with the hydroxyproline values $(r=0.79)$. Fourteen haemodialysis patients received erythropoietin therapy. In these patients, changes in the concentrations of plasma amino acids were observed up to one year after the beginning of therapy. In the course of the erythropoietin therapy, the plasma concentrations of glycine $(p<0.05)$ and hydroxyproline $(p<0.10)$ of the haemodialysis patients decreased, whereas the concentration of serine increased $(p<0.05)$ to approximately normal values. The results indicate that erythropoietin therapy leads to a normalization of amino acid metabolism.
\end{abstract}

\section{Introduction}

Osteodystrophies and elevated concentrations of hydroxyproline in plasma are closely correlated in patients with chronic renal diseases. Hence, the concentration of free hydroxyproline in plasma was recom-

\footnotetext{
1) Enzymes

Hydroxyproline oxidase (EC 1.4.3. -)

Glycine hydroxymethyltransferase

(Serine hydroxymethylase) (EC 2.1.2.1)
}

mended as a useful biochemical marker for diagnosis and therapy of bone diseases (1). Varghese et al. (1) showed that the ratio of free plasma hydroxyproline to peptide-bound hydroxyproline was unchanged in haemodialysis patients with and without visible bone condition, and concluded that catabolism is not inhibited in haemodialysis patients. Hydroxyproline is degraded in the liver to $\Delta^{1}$-3-hydroxy-pyrrolidine-5carboxylate by hydroxyproline oxidase ${ }^{1}$ ) (fig. 1). It has 


\section{The Roots of Modern Biochemistry}

\section{Fritz Lipmann's Squiggle and its Consequences}

\section{Editors Horst Kleinkauf, Hans von Döhren, Lothar Jaenicke}

$1988.17 \mathrm{~cm} \times 24 \mathrm{~cm}$. XII, 988 pages. Numerous illustrations.

Hardcover. DM 448,-; approx. US \$263.00 ISBN 3.110115859

A Fritz Lipmann dedicatory volume, originating from the Memorial Meeting held in Berlin-Dahlem in 1987, presenting the major aspects of modern biochemistry and their development in 90 essays. The Warburg/Meyerhof era, the time of emigration and postwar science are revived. Contemporaries and coworkers together with other outstanding scientists describe the state of biochemistry in major fields: as it was, as it is now, and where it will be going. At the same time this volume is a reference book on Fritz Lipmann, the outstanding biochemist, and life scientist, who considered his concept of the energy-rich bond, symbolized by the squiggle, as his major achievement.

\section{From the Contents}

Fritz Lipmann 1899-1986 • Biochemistry Comes of Age ·

Molecular Biology Sharpens its Tools - Functional Dynamics:

The Squiggle-Symbol of Bioenergetics; Molecular Recognition and Communication - Evolution - List of Contributors · Lipmann's Coworkers at Massachusetts General Hospital, Boston, and the Rockefeller University, New York · Fritz Lipmann: Bibliography 1924-1985 - Author Index · Subject Index

Price is subject to change without notice
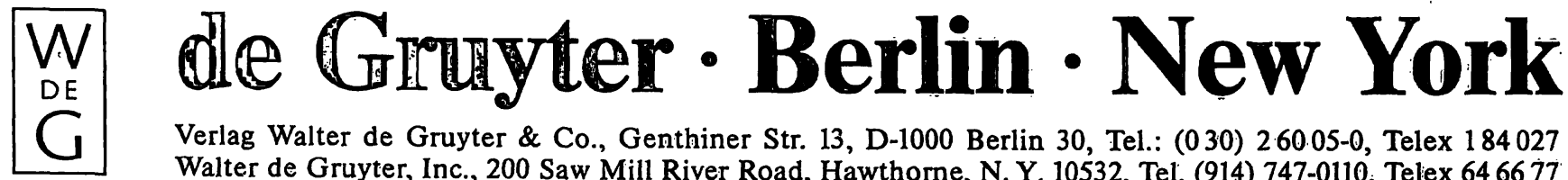


\section{Glucose analysis in seconds}

Are glucose determinations part of your routine operations?

ESAT is ideally suited to your needs. This analyzer can perform up to 120 determi-

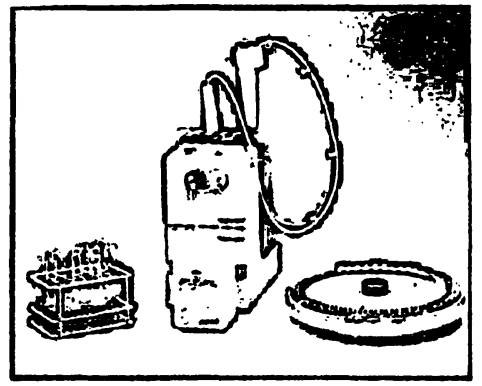

nations per hour and it is rapid, precise and cost-effective too.

\section{Do you use different types} of samples?

That is no problem for the ESAT. It can analyze the glucose concentration of whole blood, plasma and serum. Eppendorf even delivers special tubes for blood withdrawal.

\section{Eppendorf -}

Netheler - Hinz GmbH

P.O. Box 65.0670

D-2000 Hamburg 65

Telephone $(040) .53801-0$

Teletex no: $40.3061=$ EGHAM

Telefax (0 40) 53801556

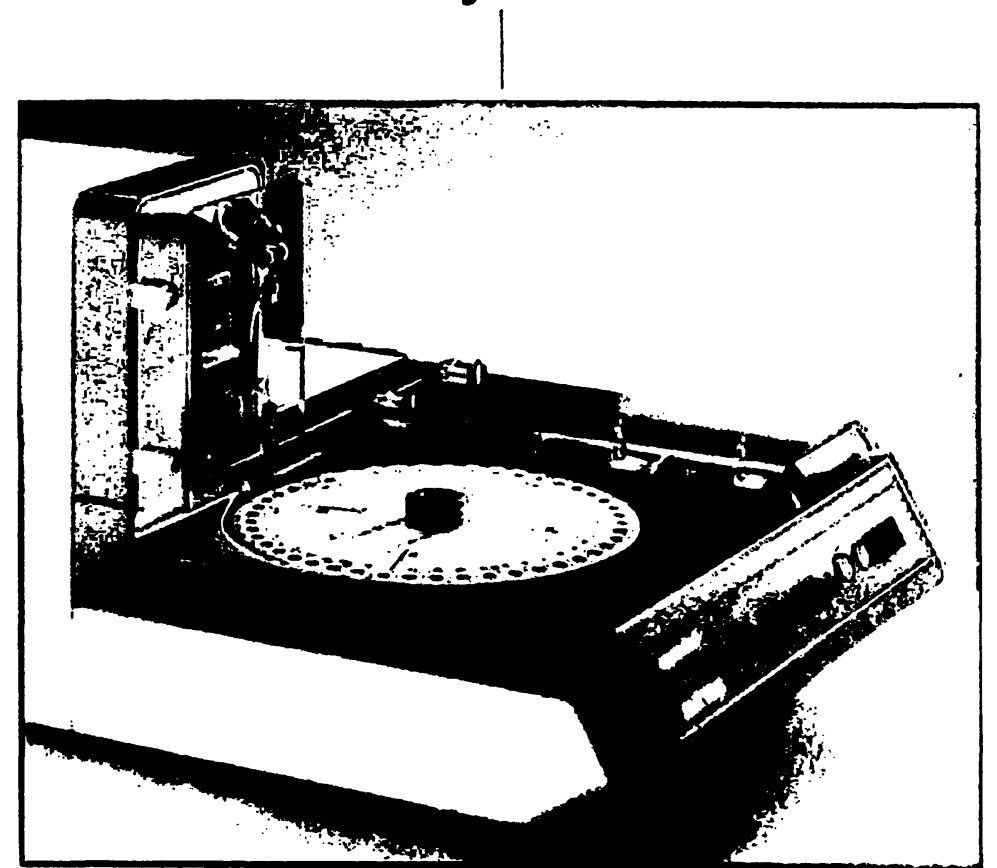

Do you require rapid results for a STAT sample?

ESAT can process a STAT sample in less than a minute.
Do you receive samples round the clock?

The ESAT is always prepared - it is ready for operation 24 hours a day.

Is your time of the essence? You will still find time for the ESAT, as it requires a minimum of operational effort. The analysis of the glucose concentration is fully automatic. Reliable data is ensured due to the analyzer's self-checking system.

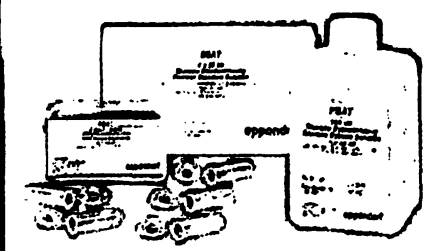

Are you looking for an allround solution?

Put us to the test. Eppendorf is your ideal partner. We offer you the complete program for your ESAT analyzer. 
been shown experimentally (2) that hydroxyproline is the main biosynthetic precursor of serine in the proximal tubulus of the kidney. Glycine is an intermediate in the degradation of hydroxyproline, and it also serves as precursor of serine biosynthesis. Plasma concentrations of serine are usually lowered in uraemic patients $(3,4)$. A disturbance of serine biosynthesis might therefore be reflected by an elevated concentration of plasma hydroxyproline, although other pathways of glycine and serine must be taken into consideration in making this interpretation.

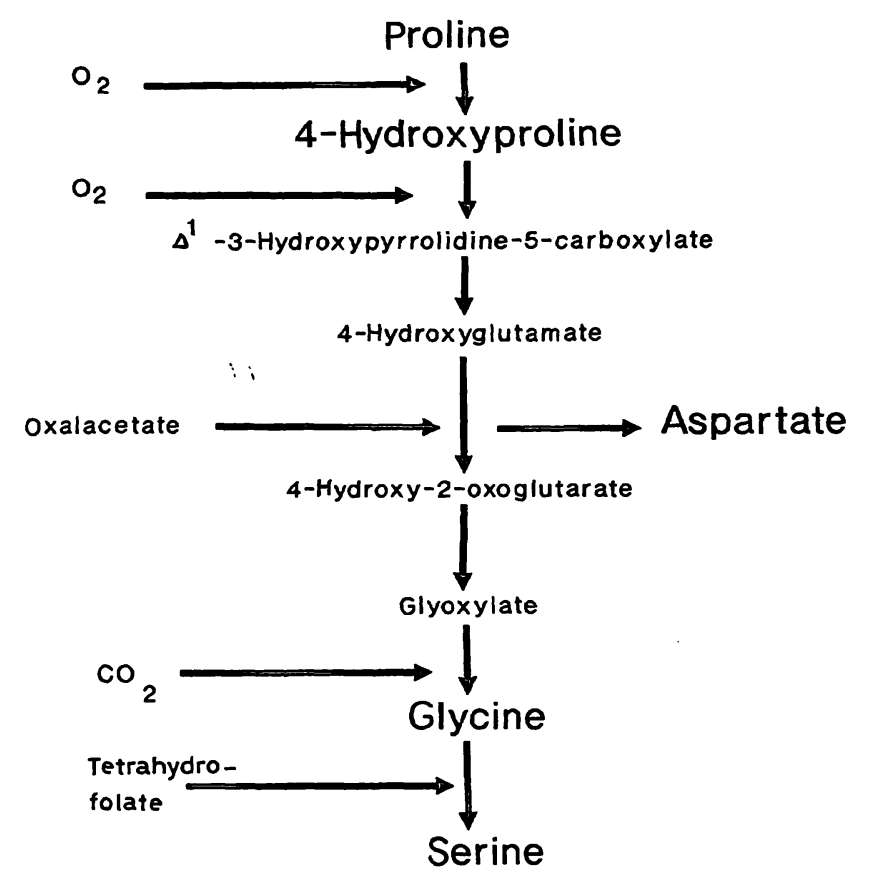

Fig. 1. Pathway of hydroxyproline metabolism in serine biosynthesis (2).

Haemodialysis patients are normally anaemic. Some metabolic disturbances in haemodialysis patients are therefore closely related to their anaemia (5). This is in part accounted for by the reduced erythropoietin biosynthesis of the diseased kidney. The reduced osmotic resistance of erythrocytes in cases of elevated plasma concentrations of parathyrin might also contribute to anaemia (6). Erythropoietin produced by genetic engineering techniques can now be used to treat anaemia in haemodialysis patients. In the present study, we have determined aspartate, glycine, proline, hydroxyproline and serine in the plasma of haemodialysis patients and healthy subjects, and we have investigated the extent to which the disturbed metabolism of these amino acids in haemodialysis patients undergoing erythropoietin therapy can be influenced by reducing anaemia.

\section{Materials and Methods}

\section{Patients}

Eighteen healthy subjects and 39 haemodialysis patients were included in the study. Fourteen of the haemodialysis patients were selected for erythropoietin therapy.

The control group included 6 male and 12 female persons from 21 to 56 years of age. The patient group included 15 men and 24 women from 21 to 76 years of age. The erythropoietin group included 2 men and 12 women from 26 to 76 years of age, who were suffering from nephronophthisis $(n=1)$, nephrosclerosis $(n=2)$, analgesia nephropathy $(n=4)$, glomerulonephritis $(n=3)$, nephrolithiasis with interstitial nephritis $(\mathbf{n}=2)$ and chronic pyelonephritis $(n=2)$. The patients were haemodialysed 3 times a week for $4-5$ hours over a period of 15 to 111 months. In the erythropoietin group, the patients were injected intravenously with $100 \mathrm{U}$ erythropoietin per $\mathrm{kg}$ body weight after each dialysis. When a haemoglobin concentration of 100 $\mathrm{g} / \mathrm{l}$ was reached, the patients were maintained at this level by individual dose reduction. Before and in course of erythropoietin therapy, all patients received phosphate lowering drugs if necessary. In course of the study 6 patients interrupted the therapy. With the consent of the patients, blood samples were collected by vein puncture in heparinized Sarstedt safety monovettes before dialysis. Recombinant human erythropoietin as freeze dried substance (BM 06.019) was a gift from Fa. Boehringer Mannheim $\mathrm{GmbH}$.

\section{Methods}

Samples

Blood samples were centrifuged for 10 minutes at $3000 \mathrm{~g}$, and $200 \mu \mathrm{l}$ plasma portions were immediately lyophilized and stored at $-20^{\circ} \mathrm{C}$.

\section{Amino acid analysis}

The following methods for amino acid analysis were applied (7).

1. Reagents and equipment

Extraction buffer: $800 \mathrm{ml}$ methanol $+200 \mathrm{ml} 50 \mathrm{mmol} / 1$ sodium acetate $\mathrm{pH}$ 7.0.

Borate buffer: $0.5 \mathrm{~mol} / \mathrm{l} \mathrm{pH} 9.5$.

Reagent I: $50 \mathrm{mg} 0$-phthaldialdehyde in $4.5 \mathrm{ml}$ methanol, 500 $\mu l$ borate buffer and $50 \mu 12$-mercaptoethanol.

Reagent III: $50 \mathrm{mg} \mathrm{o-phthaldialdehyde} \mathrm{in} 4.5 \mathrm{ml}$ methanol and $500 \mu$ l borate buffer.

Eluent A: $220 \mathrm{ml}$ methanol $+780 \mathrm{ml} 50 \mathrm{mmol} / \mathrm{l}$ sodium acetate pH 7.0.

Eluent B: $750 \mathrm{ml}$ methanol $+250 \mathrm{ml} 50 \mathrm{mmol} / \mathrm{l}$ sodium acetate $\mathrm{pH}$ 7.0.

Reagent III: $50 \mathrm{mg}$ 7-chloro-4-nitrobenż-2-oxa-1.3-diazole in $5 \mathrm{ml}$ methanol.

The following HPLC equipment was used: Du Pont 850 system, Kontron fluorescence detector SFM 23, Lichrospher RP 18 $(5 \mu \mathrm{m})$ column $(25 \mathrm{~cm}, 4.6 \mathrm{~mm}$ id.).

\section{Serine, glycine, aspartate determination}

Lyophilisates were extracted with $1000 \mu$ l extraction buffer. Extracts $(500 \mu \mathrm{l})$ were mixed with $200 \mu \mathrm{l}$ borate buffer, $50 \mu \mathrm{l}$ internal standard ( $2 \mu \mathrm{g}$ homoserine) and $100 \mu \mathrm{l}$ reagent I. After a reaction time of 10 minutes the reaction was stopped by addition of $50 \mu \mathrm{l} 0.1 \mathrm{~mol} / \mathrm{l} \mathrm{HCl}$. The reaction mixture $(50 \mu \mathrm{l})$ was diluted 1:5 with eluent $A$ and $50 \mu l$ of this dilution were injected onto the HPLC column.

Elution gradient conditions: 20 minutes $10-30 \%$ eluent $B$, linear; 20 minutes $30-100 \%$ eluent $\mathrm{B}$, linear; 5 minutes $100-$ $10 \%$ eluent $B$, linear.

Detection: Excitation at $330 \mathrm{~nm}$, emission at $450 \mathrm{~nm}$.

$$
\text { if }
$$

J. Clin. Chem. Clin. Biochem. / Vol. 27, 1989 / No. 11 
3. Proline, hydroxyproline determination

To the lyophilised plasma sample were added $500 \mu$ l extraction buffer, followed by vortexing then centrifugation for 1 minute at $3000 \mathrm{~g}$. The extract $(200 \mu \mathrm{l})$ was mixed with $100 \mu \mathrm{l}$ borate buffer, $25 \mu \mathrm{l}$ internal standard $(2 \mu \mathrm{l}$ 3.4-dehydroproline) and $50 \mu \mathrm{l}$ reagent II and incubated for 1 minute at $60^{\circ} \mathrm{C}$. Reagent III $(50 \mu \mathrm{l})$ was added and the mixture was incubated for 5 minutes at $60^{\circ} \mathrm{C}$. After addition of $25 \mu \mathrm{l} 2 \mathrm{~mol} / \mathrm{l} \mathrm{HCl}$ and $1: 5$ dilution with eluent $A, 50 \mu l$ were injected onto the HPLC column.

Elution gradient conditions: 15 minutes $10-50 \%$ eluent $\mathrm{B}$, exponent 2; 5 minutes $50-100 \%$ eluent $\mathrm{B}$, linear.

Detection: Excitation at $470 \mathrm{~nm}$, emission at $530 \mathrm{~nm}$.

The direct extraction of lyophilisates results in recoveries of amino acids up to nearly $100 \%$. Coefficients of variation for determination were (in series and from day to day, $\mathrm{n}=5$ ): serine $6.2 \%, 5.6 \%$; glycine $7.0 \%, 8.2 \%$; aspartate $4.6 \%, 8.6 \%$; proline $3.4 \%, 2.5 \%$, and hydroxyproline $2.7 \%, 2.4 \%$.

\section{Haemoglobin assay}

Haemoglobin was determined as haemiglobin cyanide (Merckotest 3317, Fa. Merck).

\section{Parathyrin assay}

Parathyrin was measured using the Human N-Tact Parathyroid Hormone-Radioimmunoassay Kit No 6900 by INC-Immuno Nuclear (Fa. IBL, Hamburg). Intact parathyrin is present in normal plasma at a concentration of $\sim 5 \mathrm{pmol} / \mathrm{l}$. Plasma also contains biologically inactive fragments (mid-region-sequence 35-64 and C-region sequence $65-84$ ) at a ratio to intact parathyrin of $100: 1$. These inactive fragments cross-react with most parathyrin radioimmunoassays (8). The $\mathrm{N}$-Tact Parathyrid Hormone kit overcomes these obstacles by an extraction and concentration procedure using specific adsorption particles, which remove intact parathyrin and $\mathrm{N}$-terminal-fragments. The correlation between biologically active parathyrin and the values determined with this kit is $95 \%$.

\section{Results}

Haemodialysis patients showed elevated plasma concentrations of glycine, hydroxyproline and proline, and significantly lowered serine values, compared with the control group (tab. 1). Plasma concentrations of hydroxyproline and parathyroid hormone (N-terminal immunoreactive parathyrin) showed no or only very poor correlation in haemodialysis patients: $y=0.68 x+10.5 \quad(r=0.54) \quad(y=$ hydroxyproline concentration $\mu \mathrm{mol} / \mathrm{l}, \mathrm{x}=\mathrm{N}$-terminal immunoreactive parathyrin concentration $\mathrm{pmol} / \mathrm{l}$ ). A correlation between plasma concentrations of hydroxyproline and $\mathrm{N}$-terminal immunoreactive parathyrin was found, however, in all patients $(n=16)$ showing highly elevated plasma $\mathrm{N}$-terminal immunoreactive parathyrin ( $>30 \mathrm{pmol} / \mathrm{l}) ; \mathrm{y}=1.15 \mathrm{x}-38.34(\mathrm{r}=0.79)$ (fig. 2$)$.

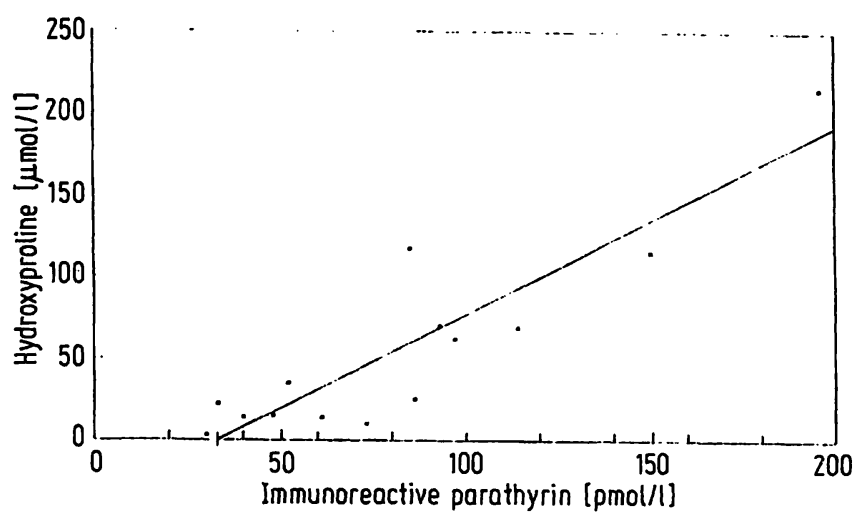

Fig. 2. Correlation of plasma concentrations of free hydroxyproline (Hyp) and parathyroid hormone (N-terminal immunoreactive parathyrin, i-PTH) in haemodialysis patients $(n=14)$

$\mathrm{c}_{\text {Hiyp }}=1.15 \mathrm{c}_{\mathrm{i}-\mathrm{PTH}}-38.34(\mathrm{r}=0.79)$.

The success of the erythropoietin therapy can be monitored by the determination of blood haemoglobin (tab. 2). The desired haemoglobin content of $100 \mathrm{~g} / 1$ was attained after approximately 12 weeks. In the 14 patients before erythropoietin therapy, plasma levels of N-terminal immunoreactive parathyrin were 22.9 $\pm 27.0 \mathrm{pmol} / \mathrm{l}$. One year after the beginning of therapy the levels of $\mathrm{N}$-terminal immunoreactive parathyrin were $14.2 \pm 10.6 \mathrm{pmol} / \mathrm{l}$. The plasma levels of calcium, inorganic phosphate and alkaline phosphatase were slightly but not significantly increased during the course of the erythropoietin therapy (tab. 3).

Tab. 1. Free concentrations of amino acids in the plasma of healthy subjects (controls) and haemodialysis patients. Significance of $t$ values by Student's $t$ index $p<0.10(*), p<0.05\left(^{* *}\right), p<0.01\left({ }^{* * *}\right)$.

\begin{tabular}{|c|c|c|c|c|c|c|c|c|}
\hline Group & $\mathrm{n}$ & & $\begin{array}{l}\text { Proline } \\
\text { بmol/1 }\end{array}$ & $\begin{array}{l}\text { Hydroxy- } \\
\text { proline } \\
\text { } \mu \mathrm{mol} / 1\end{array}$ & $\begin{array}{l}\text { Proline/ } \\
\text { hydroxy- } \\
\text { proline }\end{array}$ & $\begin{array}{l}\text { Glycine } \\
\mu \mathrm{mol} / 1\end{array}$ & $\begin{array}{l}\text { Serine } \\
\mu \mathrm{mol} / \mathrm{l}\end{array}$ & $\begin{array}{l}\text { Aspartate } \\
\mu \mathrm{mol} / \mathrm{l}\end{array}$ \\
\hline Controls & 18 & $\begin{array}{l}\text { Mean } \\
\text { S.D. } \\
\text { S. E. M. }\end{array}$ & $\begin{array}{r}192 \\
35 \\
8\end{array}$ & $\begin{array}{r}10.7 \\
5.0 \\
1.2\end{array}$ & $\begin{array}{r}21.1 \\
9.6 \\
2.3\end{array}$ & $\begin{array}{r}196 \\
52 \\
11\end{array}$ & $\begin{array}{r}94.7 \\
17.6 \\
4.2\end{array}$ & $\begin{array}{l}4.2 \\
2.2 \\
0.5\end{array}$ \\
\hline Haemodialysis group & 39 & $\begin{array}{l}\text { Mean } \\
\text { S. D. } \\
\text { S.E. M. }\end{array}$ & $\begin{array}{c}239^{*} \\
70 \\
11\end{array}$ & $\begin{array}{l}24.2^{* *} \\
15.2 \\
2.4\end{array}$ & $\begin{array}{c}14.5^{* *} \\
9.8 \\
1.6\end{array}$ & $\begin{array}{l}333 * * * \\
155 \\
25\end{array}$ & $\begin{array}{l}68.5^{* * *} \\
19.0 \\
3.0\end{array}$ & $\begin{array}{l}11.5^{* * * *} \\
6.4 \\
1.0\end{array}$ \\
\hline
\end{tabular}


Tab. 2. Haemoglobin plasma concentrations $(\mathrm{g} / \mathrm{l})$ in 14 haemodialysis patients in the course of erythropoietin therapy before, 4 weeks and 1 year after beginning of the therapy. Eighteen healthy subjects served as controls. Significance of $t$ values by Student's $t$ index in reference to therapy start $\mathrm{p}<0.05\left({ }^{* *}\right), \mathrm{p}<0.01(* * *)$.

\begin{tabular}{lclc}
\hline Group & $\mathrm{n}$ & Haemoglobin & $\mathrm{g} / \mathrm{l}$ \\
\hline Controls & & & \\
& 18 & Mean & 138.5 \\
& & S. D. & 15.7 \\
& & S. E. M. & 3.7 \\
Haemodialysis group & & & \\
Before erythropoietin & \multirow{2}{*}{14} & Mean & 61.6 \\
therapie & & S. D. & 14.8 \\
& & S. E. M. & 4.0 \\
4 weeks & \multirow{2}{*}{14} & Mean & $79.1^{* *}$ \\
erythropoietin therapy & & S. D. & 15.1 \\
& & S. E. M. & 4.0 \\
12 weeks & \multirow{2}{*}{13} & Mean & $94.4^{* * *}$ \\
erythropoietin therapy & & S. D. & 18.9 \\
& & S. E. M. & 5.3 \\
1 year & \multirow{2}{*}{8} & Mean & $93.2^{* * *}$ \\
erythropoietin therapy & & S. D. & 16.4 \\
& & S.E. M. & 5.8 \\
\hline
\end{tabular}

Surprisingly, there is a significant increase in the plasma concentration of serine, and a simultaneous, significant drop in the glycine and hydroxyproline concentrations during the correction of the anaemia (tab. 4). The slightly elevated proline concentrations observed in haemodialysis patients return to normal values after 12 weeks of erythropoietin therapy.

After one year of therapy the patient group was reduced to 8 patients. In this group, proline increased slightly and serine decreased slightly, compared with the values at 12 weeks, whereas hydroxyproline concentrations decreased further to a normal level (fig. 3).

\section{Discussion}

The occurrence of elevated glycine, hydroxyproline and proline concentrations as well as lowered serine concentrations in the plasma of patients with chronic renal disease has been known for some time $(1,3,4$, 10). However, the age-dependent increase of plasma levels of hydroxyproline should also be taken into

Tab. 3. Concentrations of calcium, inorganic phosphate, parathyroid hormone (N-terminal immunoreactive parathyrin), and alkaline phosphatase (EC 3.1.3.1) in the plasma of patients before and 1 year after beginning of erythropoietin therapy.

\begin{tabular}{|c|c|c|c|c|c|}
\hline Group & $\mathbf{n}$ & $\begin{array}{l}\text { Calcium } \\
\mathrm{mmol} / \mathrm{l}\end{array}$ & $\begin{array}{l}\text { Phosphate } \\
\text { mmol/1 }\end{array}$ & $\begin{array}{l}N \text {-terminal } \\
\text { immunoreactive } \\
\text { parathyrin } \\
\text { pmol/1 }\end{array}$ & $\begin{array}{l}\text { Alkaline } \\
\text { phosphatase } \\
\text { U/l }\end{array}$ \\
\hline $\begin{array}{l}\text { Haemodialysis patients } \\
\text { before erythropoietin } \\
\text { therapy }\end{array}$ & 14 & $\begin{array}{l}\text { Mean } 2.39 \\
\text { S. D. } 0.15 \\
\text { S. E. M. } 0.04\end{array}$ & $\begin{array}{l}1.75 \\
0.29 \\
0.08\end{array}$ & $\begin{array}{r}18.4 \\
20.2 \\
5.4\end{array}$ & $\begin{array}{r}90.3 \\
13.6 \\
3.6\end{array}$ \\
\hline $\begin{array}{l}\text { Haemodialysis patients } \\
1 \text { year after } \\
\text { erythropoietin therapy }\end{array}$ & 8 & $\begin{array}{l}\text { Mean } 2.41 \\
\text { S. D. } 0.14 \\
\text { S. E. M. } 0.05\end{array}$ & $\begin{array}{l}2.12 \\
0.44 \\
0.16\end{array}$ & $\begin{array}{r}14.2 \\
10.6 \\
3.8\end{array}$ & $\begin{array}{r}109.2 \\
32.5 \\
11.5\end{array}$ \\
\hline
\end{tabular}

Tab. 4. Concentrations of free amino acids in the plasma of 14 haemodialysis patients in the course of erythropoietin therapy before and 4,12 weeks and 1 year after beginning of therapy. Significance of $t$ values by Student's $t$ index see table 1 .

\begin{tabular}{|c|c|c|c|c|c|c|c|c|}
\hline Group & $\mathbf{n}$ & & $\begin{array}{l}\text { Proline } \\
\mu \mathrm{mol} / 1\end{array}$ & $\begin{array}{l}\text { Hydroxy- } \\
\text { proline } \\
\mu \mathrm{mol} / 1\end{array}$ & $\begin{array}{l}\text { Proline/ } \\
\text { hydroxy- } \\
\text { proline }\end{array}$ & $\begin{array}{l}\text { Glycine } \\
\mu \mathrm{mol} / 1\end{array}$ & $\begin{array}{l}\text { Serine } \\
\mu \mathrm{mol} / \mathrm{l}\end{array}$ & $\begin{array}{l}\text { Aspartate } \\
\mu \mathrm{mol} / \mathrm{l}\end{array}$ \\
\hline $\begin{array}{l}\text { Haemodialysis group } \\
\text { Before erythropoietin } \\
\text { therapy }\end{array}$ & 14 & $\begin{array}{l}\text { Mean } \\
\text { S. D. } \\
\text { S. E.M. }\end{array}$ & $\begin{array}{r}252 \\
75 \\
20\end{array}$ & $\begin{array}{r}26.2 \\
20.7 \\
5.5\end{array}$ & $\begin{array}{r}12.6 \\
7.7 \\
2.1\end{array}$ & $\begin{array}{r}317 \\
113 \\
30\end{array}$ & $\begin{array}{r}67.0 \\
15.8 \\
4.2\end{array}$ & $\begin{array}{r}11.1 \\
4.2 \\
1.1\end{array}$ \\
\hline $\begin{array}{l}4 \text { weeks } \\
\text { erythropoietin therapy }\end{array}$ & 14 & $\begin{array}{l}\text { Mean } \\
\text { S.D. } \\
\text { S. E. M. }\end{array}$ & $\begin{array}{r}237 \\
69 \\
19\end{array}$ & $\begin{array}{r}16.1 \\
9.0 \\
2.5\end{array}$ & $\begin{array}{l}18.3^{* *} \\
9.2 \\
2.5\end{array}$ & $\begin{array}{r}275 \\
79 \\
22\end{array}$ & $\begin{array}{r}75.6 \\
22.4 \\
6.2\end{array}$ & $\begin{array}{r}12.0 \\
9.1 \\
2.4\end{array}$ \\
\hline $\begin{array}{l}12 \text { weeks } \\
\text { erythropoietin therapy }\end{array}$ & 13 & $\begin{array}{l}\text { Mean } \\
\text { S.D. } \\
\text { S.E.M. }\end{array}$ & $\begin{array}{c}198 * \\
66 \\
18\end{array}$ & $\begin{array}{r}15.4 \\
13.6 \\
3.8\end{array}$ & $\begin{array}{l}18.2^{* *} \\
9.6 \\
2.7\end{array}$ & $\begin{array}{l}228^{* *} \\
56 \\
16\end{array}$ & $\begin{array}{l}87.3^{* *} \\
32.2 \\
8.9\end{array}$ & $\begin{array}{l}21.6^{* * *} \\
10.0 \\
2.8\end{array}$ \\
\hline $\begin{array}{l}1 \text { year } \\
\text { erythropoietin therapy }\end{array}$ & 9 & $\begin{array}{l}\text { Mean } \\
\text { S. D. } \\
\text { S. E. M. }\end{array}$ & $\begin{array}{r}230 \\
52 \\
17\end{array}$ & $\begin{array}{c}14.6^{*} \\
5.0 \\
1.7\end{array}$ & $\begin{array}{c}17.6^{* *} \\
4.6 \\
1.5\end{array}$ & $\begin{array}{c}155^{* * * *} \\
44 \\
15\end{array}$ & $\begin{array}{c}71.4^{*} \\
13.9 \\
4.6\end{array}$ & $\begin{array}{c}19.2^{* * *} \\
6.5 \\
2.2\end{array}$ \\
\hline
\end{tabular}




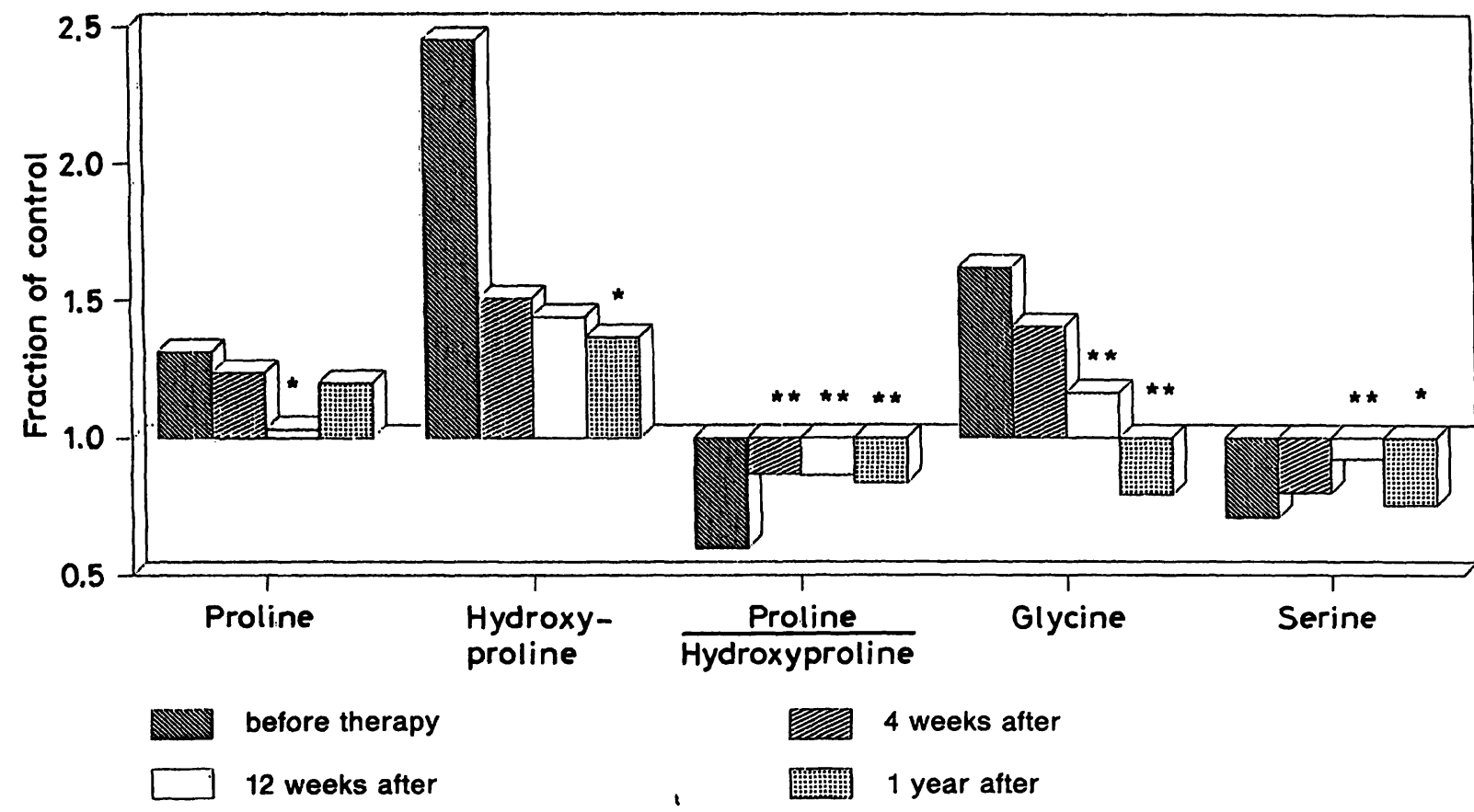

Fig. 3. Fraction of control (line 1.0, 18 healthy subjects) of plasma levels of amino acids in 14 haemodialysis patients in the course of erythropoietin therapy calculated as follows: [(patients plasma amino acid level - control plasma amino acid level $) \div$ control plasma amino acid level]. Significance of $t$ values by Student's $t$ index $p<0.10\left({ }^{*}\right), p<0.05\left({ }^{* *}\right)$ related to values before erythropoietin therapy.

consideration. The control group in our study had a mean age of $42.4 \pm 11.2$ years, while the mean age of the patient group receiving erythropoietin therapy was $63.7 \pm 13.4$ years. Gilbertson et al. (11) have proposed a procedure for calculating the age-dependent normal plasma levels of total hydroxyproline (protein-bound + peptide-bound + free). In our study we have so far measured only the free hydroxyproline plasma levels. On the basis of the Gilbertson rule, for a median age difference of 21.3 years we should correct the total hydroxyproline plasma levels by about $6 \%$. The differences between control and patient plasma levels of free hydroxyproline in our study were in the range of 144 as to $36 \%$ (fig. 3), i.e. far greater than the age-dependent differences.

A comparison of the plasma concentrations of hydroxyproline with those of parathyrin showed initially no correlation in the haemodialysis patients. However, the higher the parathyrin values, the more strongly they were correlated (fig. 2). According to Varghese et al. (1), elevated hydroxyproline values also occur without evidence of osteodystrophies. We found strongly elevated hydroxyproline values $(>30$ $\mu \mathrm{mol} / 1)$ without excessively elevated parathyrin values $(<10 \mathrm{pmol} / \mathrm{l})$ in 6 (out of 39$)$ haemodialysis patients, but not one case of low or normal hydroxyproline values with parathyrin values $>30 \mathrm{pmol} / \mathrm{l}$.

Elevated hydroxyproline concentrations in plasma appear to be the result of metabolic disturbances as well as the marker symptom of osteodystrophies. In addition, in patients suffering from renal failure, the impaired tubular reabsorption of amino acids must be considered. The unexpected drop in glycine, hydroxyproline and proline concentrations and the increase in serine concentrations towards a normalization of the amino acid level in course of the erythropoietin therapy suggests a correction of amino acid metabolism, including hydroxyproline. In the early phase of therapy (first 12 weeks), the decrease of plasma hydroxyproline concentrations showed a scatter (for standard deviations, see tab. 4). After one year of therapy this scatter vanished, and the differences became significant.

Serine is mainly produced in liver and kidney from the precursor glycine, involving the enzyme serine hydroxymethylase ${ }^{1}$ ) and the cofactor tetrahydrofolic acid (2). During the depletion of the glycine pool, there is a simultaneous degradation of plasma hydroxyproline to produce more glycine. In an intermediate step, transamination between 4-hydroxy- $L$ glutamate and oxalacetate produces 4-hydroxy-2-oxoglutarate and aspartate.

In the course of the erythropoietin therapy, the plasma concentrations of aspartate increase $(p<0.01)$. It is possible, however, that less hydroxyproline is produced during erythropoietin therapy, so that the reduction in hydroxyproline might indicate an improvement in the osteodystrophic situation (see Varghese 
et al. (1)). Further evidence for this assumption seems to be the significant increase in the ratio, proline/ hydroxyproline, during the therapy. Measurements of calcium, inorganic phosphate and alkaline phosphatase showed no significant changes during erythropietin therapy. However, all patients received continuously phosphate lowering drugs, which influence these analytes. Hence this question cannot been settled on the basis of the plasma concentrations alone, but requires detailed biochemical investigations.

Doubtless the plasma concentrations of amino acids in haemodialysis patients during erythropoietin therapy might be influenced by dietary habits (4). The patients were informed about the necessity to eliminate such potential influences, and blood samples were taken in the morning after overnight fasting.

Nevertheless, in normal adult subjects who underwent starvation, the plasma concentrations of aspartate $(-40 \%)$ and proline $(-23 \%)$ were diminished, while those of glycine $(+44 \%)$ and serine $(+9 \%)$ were elevated (12)! In our haemodialysis patients, the plasma concentrations of aspartate $(+169 \%)$, proline $(+31 \%)$ and glycine $(+62 \%)$ were elevated, while that of serine $(-29 \%)$ was decreased. These values

\section{References}

1. Varghese, Z., Moorhead, J. F. \& Wills, M. R. (1981) Plasma hydroxyproline fractions in patients with dialysis osteodystrophy. Clin. Chim. Acta 110, 105-111.

2. Lowry, M., Hall, D. E. \& Brosnan, I. T. (1985) Hydroxyproline metabolism by the rat kidney: distribution of renal enzymes of hydroxyproline catabolism and renal conversion of hydroxyproline to glycine and serine. Metabolism $34,955-561$.

3. Chami, J., Reidenberg, M. C., Wellner, D., David, D. S., Rubin, A. \& Stenzel, K. (1978) Pharmacokinetics of essential amino acids in chronic dialysis patients. Am. J. Clin. Nutr. 31, 1652-1659.

4. Young, G. A., Swanepoel, C. R., Croft, M. R., Hobson, S. M. \& Parsons, F. M. (1982) Anthropometry and plasma valine, amino acids and proteins in the nutritional assessment of hemodialysis patients. Kidney International 21 , 492-499.

5. Eschbach, J. W. \& Adamson, J. W. (1985) Anemia of endstage renal disease. Kidney International 28, 1-5.

6. Bogin, E., Massry, S. G., Levi, J., Djaldeti, M., Bristol, G. \& Smith, J. (1982) Effect of parathyroid hormone on osmotic fragility of human erythrocytes. J. Clin. Invest. 69 , 1017-1025.

7. Riedel, E., Algermissen, B. \& Nündel, M. (1988) Improved HPLC determination of free amino acids and amines in biological fluids by precolumn fluorescence derivatization. J. Prot. Chem. 7, 278-279. agree with reports of Chami et al. (3), Young et al. (4), Druml et al. (14) and others. We should expect an increase in the plasma levels of aspartate and proline and a decrease of glycine and serine as positive nutritional effects. However, in our patients we see during the erythropoietin therapy an increase in aspartate, but a decrease in proline, and glycine, and an increase in serine, although after one year of therapy the trend towards the normalization of proline and serine is slightly reversed (fig. 3). Hence the measured effects on amino acid metabolism in the course of erythropoietin therapy were only partly explained by better nutrition. Without any doubt, however, determinations of amino acid plasma concentrations, which have been greatly facilitated and improved by the newly developed high pressure liquid chromatographic fluorescence technique, will be of considerable help in monitoring the course of the disease and the therapy of haemodialysis patients.

\section{Acknowledgement}

We are grateful to Mrs. Gisela Wendel and Mrs. Heidi Schröder for excellent technical and secretarial assistance.
8. Mallette, L. E., Tuma, S. N., Berger, R. E. \& Kirkland, J. L. (1982) Radioimmunoassay for the middle region of human parathyroid hormone using an homologous antiserum with a carboxy-terminal fragment of bovine parathyroid hormone as radioligand. J. Clin. Endocrinol. Metab. 54, 1017.

9. Ali Qureshi, G., Fohlin, L. \& Bergström, J. (1984) Application of HPLC to the determination of free amino acids in physiological fluids. J. Chromatogr. 297, 91-100.

10. Minisola, S., Antonelli, R. \& Mazzuoli, G. (1985) Clinical significance of free hydroxyproline measurement in metabolic bone disease. J. Clin. Chem. Clin. Biochem. 23, 515=519.

11. Gilbertson, T. J., Brunden, M. N., Gruszczyk, S. B., Whyte, M. P. \& Burnett, M. A. (1983) Serum total hydroxyproline assay: effects of age, sex and Paget's bone disease. J. Clin. Chem. Clin. Biochem. 21, 129-132.

12. Albert, J. D., Legaspi, A., Horowitz, G. D., Tracey, K. J., Brennan, M. F. \& Lowry, S. F. (1986) Extremity amino acid metabolism during starvation and intravenous refeeding in humans. Am. J. Physiol. 251, E 604-610.

13. Fitch, W. L. \& King, J. C. (1987) Plasma amino acid, glucose, and insulin responses to moderate-protein and high-protein test meals in pregnant, nonpregnant, and gestational diabetic women. Am. J. Clin. Nutr. 46, 243-249.

14. Druml, W., Bürger, U., Kleinberger, G., Lenż, K. \& Laggner, A. (1986) Elimination of amino acids in acute renal failure. Nephron $42,62-67$.

Prof. Dr. Eberhard Riedel

Institut für Biochemie

der Freien Universität Berlin

Limonenstraße 7

D-1000 Berlin 45 